\title{
SOILS OF WANGANUI DISTRICT
}

\author{
J. D. COWIE \\ Soil Bureau, D.S.I.R., Palmerston North
}

I. B. Самpbeli

Soil Bureau, D.S.I.R., Wanganui

THE Wanganui district includes the counties of Wanganui, Waitotara, Waimarino and Rangitikei, and soil surveys embracing this area comprise :

( 1 ) The 4-inch to the mile survey of the North Island (Soil Bureau, 1954).

(2) The sand country soil association survey, which mapped the sand country as far north as Whangaehu River (Cowie and Fitzgerald, in press).

(3) A detailed survey of the soils of Flock House Farm of Instruction near Bulls (Cowie and Hall, 1965).

A survey of Wanganui County at a scale of 1 mile to 1 inch has just been started and this is to include a special study on the mechanism of erosion and its relation to soils.

The Wanganui district as defined is a roughly rectangular area of about $1 \%$ miliion acres and extends inland from the coast to the central volcanic plateau at an altitude of over 2,000 ft. Although the landscape within this district is varied, three broad topographic units can be recognized. These are:

(1) The coastal plain consisting of the sand country, terraces and alluvial flats;

(2) The hill country with mainly steep and moderately steep slopes on sedimentary rocks;

(3) The volcanic plateau of the Ohakune-Waiouru district.

A detailed description of the geology of the Wanganui district and the evolution of the present landscape is given by Fleming (1953). In Tertiary times, a large ocean basin occupied what is now the Wanganui district and considerable quantities of mud, sand, shell and gravel were deposited into this. These sediments were subsequently consolidated, hardened and cemented to form the papa, sandstone, shell limestone and conglomerate that are char- 
acteristic of much of this district. Uplift began in late Tertiary times and has continued to the present day, raising these rocks to their present positions. This continued uplift and the rapid downcutting by rivers and streams has given rise to the present immature landscape with steep-sided valleys.

In late Pleistocene times, alluvial plains and dune complexes were built up to form an extensive coastal plain. This was later uplifted, cliffed by the sea and dissected by rivers to form the distinctive high terraces which occur in the Fordell, Westmere and Nukumaru districts.

Following the formation of these high terraces, volcanic activity took place in Taranaki and the central North Island and fine textured andesitic ash was deposited widely over the Wanganui district. These ash deposits are several feet thick in the Ohakune part of the district and thin out gradually to the south and east. On the hill country, most of the ash that fell was subsequently washed off the slopes. On the coastal terraces, the ash deposits were also thin and were mixed with loess and sand blown from braided river courses and from coastal dunes.

In recent times, continued erosion of the hill and terrace country has furnished large quantities of detritus from which the alluvial flats and the coastal dune complex have been formed. Eruption of the Taupo Ash, which occurred in A.D. 200, covered only a small area in the northern end of Wanganui district but huge Roods of pumice sand and boulders were carried down the Wanganui and Rangitikei rivers and deposited along their lower reaches. The latest volcanic eruptions are those of Ruapehu and Ngauruhoe and ash from these volcanoes has accumulated as a grey sand in the Desert Road area.

\section{Soils}

The soil pattern in the Wanganui district closely follows that of the topographic units described previously and is discussed according to this grouping. The accompanying soil map and descriptions are derived chiefly from the general survey of the soils of the North Island (Soil Bureau, 1954).

(1) Soils of the Coastal Plain

The coastal plain extends inland to about 8 miles from the coast, rising in places to $800 \mathrm{ft}$ above sea level. Annual rainfall is from about 38 to $40 \mathrm{in}$. and the climate is characterized by dryish summers. The soils of the coastal plain include several groups of soils. 


\section{(a) SoIls of the SAND Country}

Soils of the sand dune complex include yellow brown sands, sandy gley soils and organic soils formed mainly from coarse textured wind blown sands. These soils are often thought to be homogeneous. Detailed study, however, has shown they have a wide range of properties reflected in their range of land use and farming potential. Nearest the coast are droughty and unstable Waitarere soils with weakly developed profiles. Large areas are bare and drift on to farmed areas. Forestry projects have shown that they can be stabilized and such projects, as well as protecting inland farmland, provide an economic use for this land. A mixed pattern of farming and forestry is possible where there are larger areas of wet sand plains (Hokio soils) which support good pastures.

Inland, where the dunes are consolidated and the soils have developed profiles, pastoral farming is successful, especially where there are larger areas of sand flat with a high watertable (Pukepuke and Carnarvon soils). The high watertables ensures an adequate supply of moisture through the main growing period for high-producing pastures, as. well as providing plant nutrients. These soils require some drainage but this should be shallow as permanent lowering of the water-table would remove one of the factors making good pasture growth possible.

The soils on the drier sand flats and dunes (Himatangi, A wahau and Foxton soils) are less suited to pastoral farming, mainly because of their droughtiness, but could be farmed more intensively by the adoption of dryland farming techniques. Supplementary irrigation using the underlying groundwater could also be of value. On these areas of drier soils, forestry offers a very satisfactory alternative form of land use, as Chisholm (1965) has shown that this can give a better economic return than the present form of land use.

Most of the sand country soils are deficient in phosphorus and potassium, and pastures respond to these as well as lime. Lime depression has been noted on some soils, however, and copper, selenium and cobalt deficiencies in stock have been recorded.

\section{(b) Solls of the Alluvial Flats}

These soils, formed from recent alluvium, are restricted chiefly to the lower reaches of the Wanganui, Whangaehu and Rangitikei rivers. They are young soils with little profile development differing mainly because of natural drainage, 
nature and texture of the alluvium and rate of accumulation of alluvium. Recent soils with good natural drainage, e.g., Manawatu silt loam, are deep, friable and fertile and except for those that are frequently flooded can support highproducing pastures and are suitable for intensive cropping. The recent soils are generally well supplied with phosphorus and potassium and only lime and light phosphate dressings are required for optimum pasture growth.

Soils with poor natural drainage are classified as gley recent soils (Parewanui and Kairanga soils). These have a high natural fertility but poor winter drainage is a limiting factor to high pasture production. When drained, however, they support good pasture and are suitable for annual cropping. The soils of the recent Taupo pumice alluvium are coarse textured sands and gravels but with heavy topdressing support fairly good pasture and are also used for horticulture.

\section{(c) Solls of the Terraces}

These are the third group of soils on the coastal plain and are formed from a mixture of loess and volcanic ash, the proportions of which are variable. South of the Wanganui River, the soils are mostly from loess and have grayish or black topsoils with compact, mottled, heavy textured subsoils. These are classed as gleyed yellow grey earths, e.g., Ohakea, Marton and Halcombe soils. Winter drainage is poor and adequate artificial drainage and topdressing with phosphate, lime and potash is necessary for high pasture production. These soils, however, dry out in summer and pasture production is resricted accordingly.

North-west of the Wanganui River and north of Marton, the proportion of ash increases and the soils grade into yellow brown loams, similar to those of the Taranaki district (Westmere and Kiwitea soils). Topsoils are dark brown or black with strongly developed structures and subsoils are yellowish brown, weakly mottled and slightly compact. With these soil properties, winter drainage is better than in the yellow grey earths and they do not dry out in summer. As rainfall is somewhat higher and because of their moisture status and physical properties they are well suited to pastoral farming. This is reflected in the farming pattern as there is a change from fat lamb farming and cereal cropping on the yellow grey earth of the Rangitikei district to fattening, stud farms and dairying on the yellow brown loams. 


\section{SOIL MAP OF WANGANUI DISTRICT}

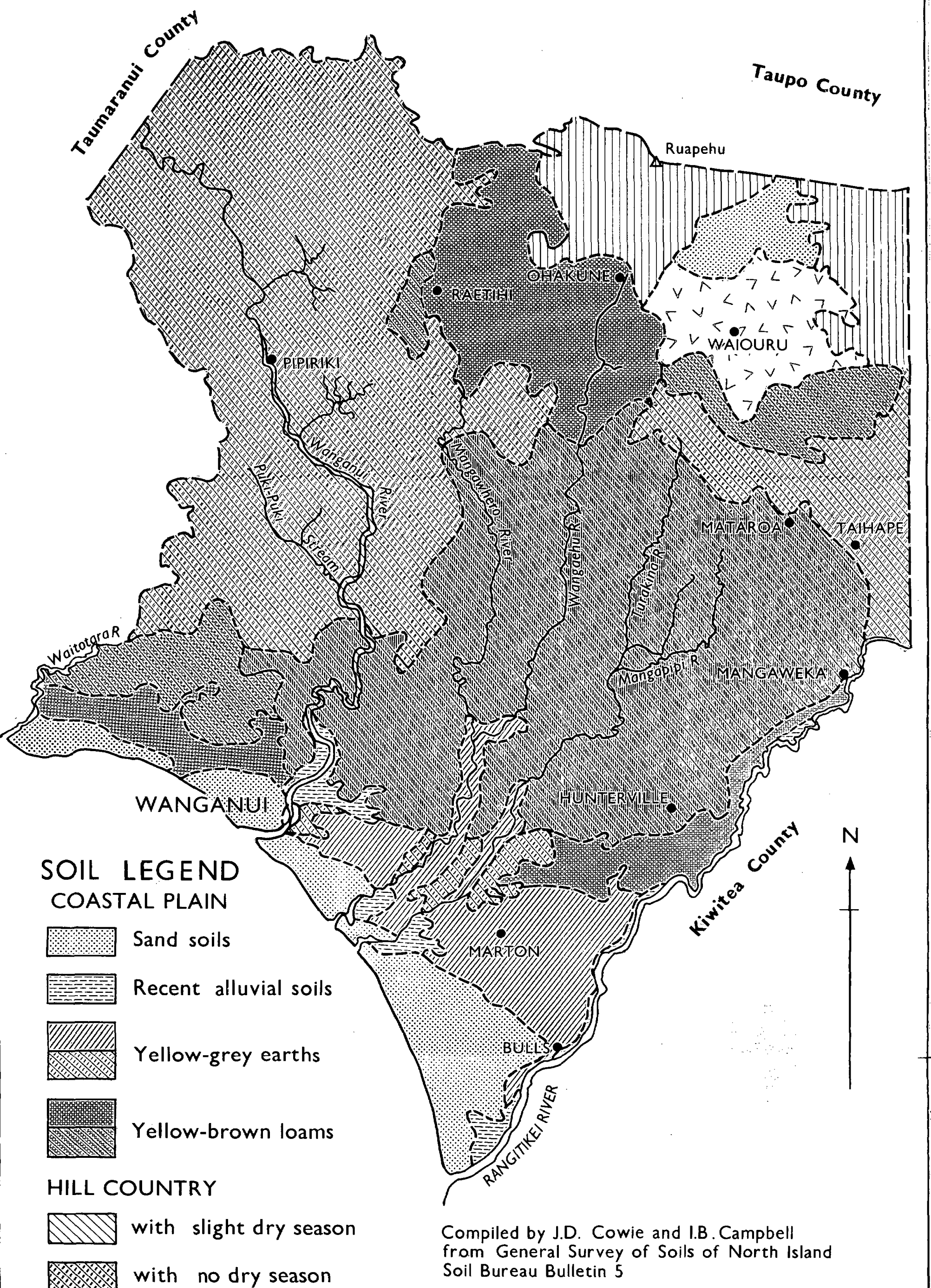

VOLCANIC COUNTRY

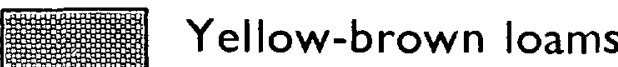

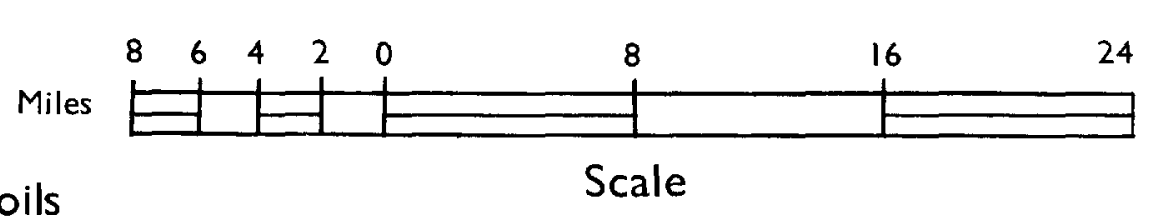

${ }^{1} v^{>}$Yellow-brown pumice soils

Recent volcanic ash soils

Mountainous land

Dill and steepland soils 
(2) Solls of the Hill Country

The soils of the hill country are formed mainly on moderately steep and steep slopes from sedimentary rocks. Two main soil divisions, based on climate, are recognized within this unit. The first are classed as intergrades between yellow grey and yellow brown earths and related steepland soils. They are formed under a moderate rainfall with a pronounced summer dry season and are characterized by slightly compact, yellowish grey heavy textured subsoils with yellowish brown mottles. In some places, but especially nearer the coast, the soils dry out during the summer dry period. On many slopes there is considerable regeneration of manuka and gorse (Kumeroa hill soils, Whangaehu and Pohangina steepland soils).

As rainfall increases towards the north-west, the summer dry season is less pronounced. Here Mangaweka hill soils and related Taihape steepland soils occur on grey siltstones and fine sandstones and good pastures can be maintained on these soils with phosphate topdressing. Numerous shallow slips occur but these regrass readily. Mangamahu steepland soils are from hard sandstone and formerly supported beech forest. Their level of fertility is low and erosion results in many slips which do not heal quickly. Bare areas and cooler faces regenerate to fern and scrub and as it is difficult to maintain good pastures most areas may be better suited for forests.

The second group of soils, the yellow brown earths and related steepland soils, occur where rainfall is above or about 50 in. There is no summer dry season and the soils have dark brown topsoils and friable yellowish brown subsoils. Turakina steepland soils and related Mangatea hill soils are formed from bluish grey mudstones and siltstones and are fertile soils supporting good pastures. They are, however, subject to severe slumping with many shallow slips and adequate conservation measures are necessary to prevent severe soil losses. The soils formed from coarse grained hard sandstone under beech forest (Whangamomona and Moumahaki soils) have a low natural fertility. These are subject to numerous shallow slips which take a long time to heal and pastures tend to revert to scrub and fern.

Several feet of andesitic ash occurs on many of the easier rolling and hilly slopes and these soils are deep, friable and stable. With heavy dressings of phosphate and potash, improved pastures can be maintained and the grazing thus 
provided enables greater development and use to be made of the adjacent poorer hill country.

Many of the steep and hill country soils of the Wanganui district have a high potential production under grassland farming and could be farmed if necessary. However, the soils vary considerably in their potential production, in the effort required to maintain high pastoral production and in their stability under pasture.

Instability of the soil under pasture is one of the chief problems in the hill country. Rapid downcutting by streams and rivers has led to oversteepening of valley sides. In natural. conditions, when the land was covered by forest, tree roots held the soil together and although some slips occurred erosion was a fairly slow process and soil formation kept pace with it. The pasture replacing the bush had only a shallow root system and as the soil was not strongly held together accelerated erosion commenced.

The soils formed 'on slopes which are underlain by an indurated and impermeabie siltstone and sandstone (Mangamahu, Whangomomona and Moumahaki soils), or where there is a sharp boundary between the soil and underlying parent material (Kumeroa and Whangaehu soils), are especially susceptible to slips, as moisture which move along this layer lubricates potential slip planes. On soils with less indurated and more permeable parent materials (Ohakune hill soils), slips are less frequent. However, gullying may occur readily where the underlying rocks are soft and unconsolidated sands (Pohangina soils).

If this country is to be farmed, one may have to accept and live with a certain amount of soil erosion, but future land development should have adequate soil conservation measures as an integral part of the development programme. On land already farmed, conservation that is being encouraged by local catchment boards should be continued and expanded. Development programmes should consider the effects of increased run-offs with the change from forest and scrub to pasture, for it may prove wisest to retain soils of low natural fertility in forest as protection for fertile lowland areas.

\section{(3) Sollls of the Volcanic Plateau}

These soils occur mainly above $2,000 \mathrm{ft}$ on rolling and hilly slopes surrounding Mount Ruapehu and are formed from ash of the Tongariro, Taupo and Ngauruhoe ash showers. The earliest and most widespread was the ande- 
sitic and silty Tongariro shower. This eruption was intermittent and as the ash accumulated only gradually, the vegetation continued to grow through it and the soils are deep, friable and yellowish brown in colour. They are classed as yellow brown loams and include Moawhanga, Ohakune and Pokaka soils. They are well drained, can. be cultivated for a large part of the year and have proved ideal for growing vegetables.

The yellow brown loams have a moderate natural fertility. They are high in the clay mineral allophane and have a high fixing power for phosphate. Regular and heavy applications of phosphate as well as potash are required for satisfactory pasture growth. Rainfall is generally adequate for summer pasture growth, and, apart from fertilizers, the main limitation of these soils for pasture growth is the cold winter period.

Taupo ash was a later rhyolitic ash which was erupted violently over a short period of time. It covered only a small area of the north-eastern part of Rangitikei County where ash was thinly deposited over the older Tongariro ash. Soils on Taupo ash are classed as yellow brown pumice soils and include Taupo, Waimarino and Kaiangaroa soils. These are sandy in texture and of lower nutrient supply than the adjacent yellow brown loams, being deficient in phosphorus, potassium, sulphur, cobalt and selenium. As on soils of the Tongariro ash, pasture growth is limited by low winter temperatures.

The youngest ash is the Ngauruhoe ash on which Ngauruhoe sand is formed. Only a small area of this soil occurs in the district and it is not farmed intensively because of the rigorous climate which severely limits pasture production. There are some associated steepland soils with a thin cover of ash over volcanic rocks and greywackes. They are of fairly low natural fertility and are mostly in forest or tussock. The mountain soils on the slopes of Ruapehu are shallow and stony.

\section{Soil Classes for Potential Pastoral Use}

The soil pattern of the Wanganui district as described is complex, and, because of this, the potential for pastoral production is variable. Using the knowledge of the properties of the soils such as their level of nutrients, moisture and temperature regimes, slope, stability and farming experience on them, they can be grouped into six classes for potential pastoral use and production. 
This classification follows that outlined by Gibbs (1963) and summarizes present knowledge of these soils.

Cuass I comprises the soils of flat and rolling land with slight soil limitations to pastoral use and production. Usually these limitations are those of poor drainage or nutrient supply-limitations which can be readily corrected. This class includes the soils of the alluvial flats and terraces. As well as being capable of high pasture production they are also very suitable for cropping.

CLASS II comprises the soils of flat or rolling land with moderate soil limitations to pasture production. They include the yellow brown loams and yellow brown pumice soils of the volcanic plateau where cold winter temperatures (and low nutrient supply) are limiting factors and many of the sand country soils where there is excessive drainage.

CLASS III comprises the soils of flat and rolling land with severe soil limitations to pastoral use and production. This class includes the recent soils from $\mathrm{N}$ gauruhoe ash where the very cool climate is limiting; the frequently flooded soils along the river berms; and the droughty and unstable sandy soils along the coast. Intensive pastoral farming is a doubtful proposition on these soils.

Ciass IV comprises the soils of hilly and steep land with slight to moderate soil limitations to pastoral use. It includes the more fertile of the hilly and steepland soils, such as Mangatea, Mangaweka, Ohakune and Turakina soils, and the limitations are those of slope and slight instability.

CLAss $V$ comprises the soils of 'the hilly and steep land with moderate to severe soil limitations to permanent pastoral use. These limitations include one or more of the following factors apart from the slope: severe instability; low nutrient supply; summer droughtiness ; cool winter temperatures. Typical of this class are the Kumeroa, Whangaehu, Taihape, Moawhango and Pohangina soils. Continued pastoral production is possible on these soils but adequate soil conservation measures need to be taken to prevent serious soil erosion and high amounts of fertilizers may be needed. Where the limitation is one of climate, potential pasture production will be lower than on the soils of Class IV.

CiAss VI comprises the soils with severe to very severe soil limitations to pastoral use and production. These limita- 
tions include one or more of the following: very severe instability ; very low nutrient supply ; cool winter climate. Included in this class are the Whangamomona, Moumahaki, and Kaimanawa soils. Continued pastoral farming is doubtful on these soils and they would be best returned to or retained in forest.

In the area comprising the Wanganui district, the individual totals of classes are as follows:

$\begin{array}{llll}\text { Class I } & 174,000 \text { acres } & \text { Class IV } & 300,500 \text { acres } \\ \text { Class II } & 175,000 \text { acres } & \text { Class V } & 496,500 \text { acres } \\ \text { Class III } & 50,000 \text { acres } & \text { Class VI } & 519,000 \text { acres }\end{array}$

Mountain soils, 35,000 acres

These figures show that there are approximately 1,150,000 acres $(66 \%)$ in the Wanganui district which are well suited to pastoral farming. Of this, 797,000 acres is moderately steep or steep land. This is the land from which the most worthwhile increases in production will come, but it will also be the land which will present the greatest problems and offer the greatest challenge to grasslands workers.

\section{REFERENCES}

Chisholm, A. H. (1963): An economic comparison of forestry and agriculture. Discussion Paper No. 30. Department of Agricultural Economics and Farm Management, Massey University, Palmerston North.

Cowie, J. D.; Fitzgerald, P. (In press) : Soils of the Manawatu-Rangitikei sand country. N.Z. Soil Bur. Bull.

Cowie, J. D.; Hall, A. D. (1965) : Soils and agriculture of the Flock House Farm of Instruction, Bulls, Manawatu, N.Z. N.Z. Soil Bur. Rep. 1/65.

Fleming, C. A. (1953): The geology of Wanganui Subdivision. N.Z. Geol. Surv. Bull. 52

Gibbs, H. S. (1963): Soils of New Zealand and their limitations for pastoral use. N.Z. Soil BUY. Publ. No. 308. (N.Z. Institute of Agricultural Science Proceedings, 1963, 9: 63-79).

N.Z. Soil Bureau 1954: General survey of the soils of North Island, New Zealand. N.Z. Soil Bur. Bull. 5. 


\section{DISCUSSION}

It was mentioned that nearly a million acres of hill country in the Wanganui district were suitable for grassland farming. On how much of this would the results of the work of Grasslunds Division at Te Awa be applicable?

Many of the hill country soils are very similar to those at Te Awa and there is no doubt that the principles found there could bc equally well applied in the hill country of the Wanganui district with similar results.

Could Mr Cowie tell us at what level of ewe equivalents per acre Mr Chisholm considered forestry more profitable than farming?

This figure was not given in Mr Chisholm's study. He took a figure of 3.5 ewe equivalents per acre as the potential carrying capacity on sheep-beef farms and then compared the profitability of farming versus forestry on various soil types.

It was mentioned that slips were more common on sunny than shady faces. What is the reason for this?

Several factors are probably responsible for this. Pastures are often grazed more intensively on sunny faces because these warm slopes rather than the cooler faces are prefcrred by the grazing animal, and sheet erosion under the reduced pasture cover is more intensive. Sunny faces also dry out more readily than shady faces, especially where the pasture is open. In such situations the soil shrinks and cracks as it dries. This allows easy penetration of moisture into the soil when rains follow dry spells. This rapid influx of moisture seeps between the underlying rock and soil and provides a lubricated plane along which many slips commence movement. 